\title{
Ridha Terhadap Citra Tubuh Pada Remaja
}

\author{
Mery Atul Kiptiah \\ Universitas Islam Negeri (UIN) Antasari
}

\begin{abstract}
The aim of the study is the prove Ridha relationship to body image in students High school. The incompatibility of body conditions with an ideal body image encourages adolescence to change body shape so that confidence increases. This behavior is the implementation of negative body image so that adolescence need to increase self-acceptance or Ridha. Correlational research type with a quantitative approach. The sample population of student class XI and using purposive sampling with a total of 124 samples. Research data collected using the Ridha scale and body image consisting of 26 and 22 valid items with a reliability coefficient of 0,859 and 0,834. The results showed that there is a positive relationship between Ridha with the body image of adolescents which means the higher Ridha then the more positive body image with correlation coefficient $r x y=0,324 ; p=0,000(p<0,01)$. R-Square obtained by 0,105 means that being Ridha to contribute effectively is $10,5 \%$ to body image.
\end{abstract}

Keywords: Adolescence; Body image; Ridha

\begin{abstract}
Abstrak
Tujuan penelitian ialah membuktikan hubungan ridha terhadap citra tubuh pada siswa SMA. Ketidaksesuaian kondisi tubuh dengan gambaran tubuh ideal mendorong remaja untuk mengubah bentuk tubuh agar kepercayaan diri meningkat. Perilaku tersebut ialah implementasi dari citra tubuh negatif sehingga remaja perlu meningkatkan penerimaan diri atau ridha. Jenis penelitian korelasional dengan pendekatan kuantitatif. Populasi sampel siswa kelas XI dan menggunakan purposive sampling dengan jumlah 124 sampel. Data penelitian dikumpulkan menggunakan skala ridha dan citra tubuh terdiri dari 26 aitem dan 22 aitem valid dengan koefisien reliabilitas sebesar 0,859 dan 0,834. Hasil penelitian menunjukkan bahwa terdapat hubungan positif antara ridha dengan citra tubuh remaja artinya semakin tinggi ridha maka semakin positif citra tubuh dengan koefisien korelasi $r_{x y}=0,324 ; p=0,000(p<0,01)$. R square yang diperoleh sebesar 0,105 artinya ridha memberi sumbangan efektif sebesar 10,5\% terhadap citra tubuh.
\end{abstract}

Kata Kunci: Citra tubuh; Remaja; Ridha

Saat manusia dilahirkan normalnya ia akan tumbuh dan berkembang dari masa ke masa. Pada fase tertentu seseorang akan dituntut untuk lebih dewasa baik secara mental maupun psikis dan salah satu fase yang harus dilalui ialah masa perkembangan remaja. Remaja (Hurlock, 1980) berasal dari kata adolescence yang artinya tumbuh menjadi dewasa, dalam artian 
yang lebih luas mencakup kematangan mental, emosional, sosial dan fisik. Perubahan yang cukup menonjol saat memasuki masa remaja ialah perubahan fisik yang dimulai ketika seorang remaja telah mengalami pubertas, yaitu masa kematangan fisik yang cepat, dimana melibatkan perubahan hormonal dan tubuh yang terjadi terutama pada masa remaja awal (Husni \& Indrijati, 2014). Salah satu aspek psikologis dari perubahan fisik pada masa pubertas adalah remaja amat memperhatikan tubuh mereka dan membangun citranya sendiri bagaimana tubuh mereka (Dwinanda, 2017). Perhatian yang diciptakan remaja akan tubuhnya membuat mereka merasa khawatir saat mengalami masa haid, tumbuhnya jerawat dan ganggguan kulit, serta kecenderungan menjadi gemuk (Hurlock, 1980).

Hurlock memaparkan bahwa kesadaran akan adanya reaksi sosial terhadap berbagai reaksi bentuk tubuh menyebabkan remaja prihatin akan pertumbuhan tubuhnya yang tidak sesuai dengan standar budaya yang berlaku (Hurlock, 1980). Menurut Hurlock (1980) meskipun pakaian dan alat-alat kecantikan dapat digunakan untuk menyembunyikan bentuk-bentuk fisik yang tidak disukai remaja dan untuk menonjolkan bentuk fisik yang dianggap menarik tetapi belum cukup untuk menjamin adanya kateksis tubuh atau merasa puas dengan tubuhnya. Hurlock (1980) menyebutkan hanya sedikit remaja yang mengalami kateksis tubuh atau merasa puas dengan tubuhnya.

Berdasarkan penjelasan di atas bahwa ketidakpuasaan yang dirasakan remaja tidak hanya dikarenakan oleh perubahan fisik di masa pubertas namun juga adanya reaksi sosial dan standarisasi tertentu mengenai bentuk tubuh. Bahkan dalam sebuah penelitian (Sarwer, Thompson, \& Cash, 2005) disebutkan bahwa based on the result of the survey published in psychology today, most women (56\%) and almost half (43\%) of men are dissatisfied with their overall appearance yang artinya menurut hasil survei Psychology Today bahwa 56\% wanita dan kurang lebih $43 \%$ pria tidak puas terhadap keseluruhan penampilan mereka. Faktor lain yang turut mendukung pentingnya penampilan bagi remaja ialah pengaruh media. Karena menurut Husni dan Indrajati (2014) selama masa remaja media merupakan faktor sosiokultural yang mempromosikan berbagai hal yang berhubungan dengan penampilan. Hal ini disebabkan oleh kurangnya kepercayaan diri sehingga timbul perilaku mengubah bentuk tubuh dengan operasi kosmetik yang lebih diminati oleh individu-individu zaman sekarang, bagi mereka yang 
memiliki kepuasan tubuh yang rendah (Dwinanda, 2017). Sesuai dengan hasil observasi peneliti bahwa fenomena perilaku mengubah bentuk tubuh hingga operasi kosmetik mulai marak terjadi di salah satu kecamatan di kabupaten Paser, Kalimantan Timur, khususnya di kalangan remaja yang duduk di bangku SMA. Bagi beberapa orang hal tersebut merupakan kemajuan teknologi yang harus dinikmati dan diikuti, namun dari sisi lain ada norma-norma agama yang seharusnya tidak dilanggar, terlebih lagi mengubah bentuk tubuh hingga operasi kosmetik yang tidak disukai oleh Allah ta'ala.

Hadis yang diriwayatkan oleh Abdullah bin Mas'ud, (al-Mundziri, 2003) yang artinya: "Allah melaknat perempuan yang menato dan yang meminta ditato, yang menghilangkan bulu di wajahnya dan yang meminta dihilangkan bulu di wajahnya, yang merenggangkan giginya supaya terlihat cantik, juga perempuan yang mengubah ciptaan Allah. Hadis menjelaskan berbagai larangan mengenai mengubah bentuk tubuh hingga operasi kosmetik yang tidak dianjurkan sehingga Allah melaknat siapapun yang melakukannya. Adapun terlaknat ialah jauh dari rahmat Allah ta'ala.

Hasil wawancara dan observasi lapangan menunjukkan bahwa penampilan cukup penting bagi remaja hal ini sesuai dengan pernyataan Santrock yang telah disebutkan sebelumnya. Pentingnya penampilan bagi remaja tidak lepas dari istilah citra tubuh. Cash dan Pruzinsky (Yuliadi \& Karyanta, 2014) menjelaskan bahwa citra tubuh adalah sikap yang dimiliki individu terhadap tubuhnya, dapat berupa penilaian positif maupun negatif. Ketidaksesuaian antara keinginan individu dengan realita yang ada membuat remaja berpikir untuk mengubah bentuk tubuh menjadi lebih ideal atau menjadi seperti apa yang ia inginkan. Menurut Goldfield (Hasni, Karini, \& Andayani, 2013) seseorang yang merasa tidak puas dengan bentuk tubuhnya menunjukkan adanya gejala depresi yang lebih berat seperti anhedonia, harga diri negatif, dan tingginya angka depresi daripada mereka yang memiliki kepuasan tinggi.

Berbagai gejala atau dampak yang diakibatkan oleh kurang puas terhadap citra tubuh, seharusnya mampu diatasi oleh para remaja, dalam artian remaja mampu menerima apa yang sudah dimiliki dan berusaha merelakan apa yang memang tidak bisa dicapai selama ini. Rela dan menerima (Kemdikbud, 2017) yang dimaksudkan ialah sikap ridha seperti dalam Kamus 


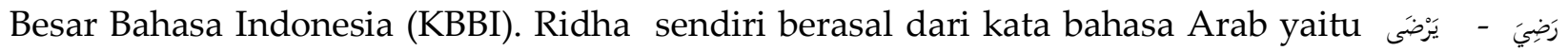
atau radhiya - yardho, yang artinya senang, suka, atau rela (Munawwir, 1997). Ridha merupakan bentuk pencapaian kebahagian yang khas bagi umat Islam. Menurut Ibnu Qayyim (1998), ridha ialah menerima qada dan qadar dengan kerelaan hati, yaitu menerima ketetapan Allah ta'ala dengan kerelaan hati. Abdul Mujib (2017) menyebutkan bahwa ridha (radhi), ialah rela terhadap apa yang dimiliki dan diberikan. Karakter ini hanya terkait pada kelapangan dan kebesaran jiwa atas apa yang diberikan oleh Allah ta'ala tanpa rasa mengeluh atau menderita karenanya. Ridha tidak disyaratkan untuk tidak merasakan penderitaan dan hal-hal yang tidak disukai. Tetapi keadaan ini tidak boleh dihadapi dengan kemarahan atau penolakan takdir. Sebab bagaimana mungkin ridha dan kebencian bisa menyatu padahal keduanya saling bertentangan.

Ibnu Qayyim (1998) menjelaskan bahwa ridha adalah sesuatu yang bisa diupayakan ditilik dari sebabnya, dan merupakan pemberian jika ditilik dari hakikatnya. Ibnu Mas'ud (alMaqdisy, 2012) menjelaskan bahwa sesungguhnya Allah ta'ala menjadikan kenyamanan dan kesenangan ada dalam keyakinan dan keridhaan, menjadikan kekhawatiran dan kesedihan dalam keraguan dan kemarahan. al-Hasan berkata (al-Maqdisy, 2012) dalam Minhajul Qashidin, yaitu:

“Siapa yang ridha terhadap apa yang diberikan kepadanya, niscaya Allah ta'ala akan melapangkan dan memberkahinya dan siapa yang tidak ridha, maka Dia tidak melapangkan dan tidak pula memberkahinya". Kemudian Nabi Daud bertanya: "Wahai Rabbi, siapakah hamba yang paling Engkau murkai?", Allah ta'ala menjawab "Hamba yang memohon pilihan terbaik kepada-Ku dalam suatu urusan, lalu Aku memilihkan baginya yang terbaik, namun dia tidak ridha".

Keridhaan merupakan tahap merelakan dan menerima terhadap apa yang diberikan oleh Allah ta'ala. Tubuh merupakan salah satu anugrah pemberian Allah ta'ala dengan berbagai ketetapan dan proporsi yang telah ditentukan-Nya, seperti dalam Q.S. at-Tin/95: 4, yang artinya: "sesungguhnya Kami telah menciptakan manusia dalam bentuk yang sebaik-baiknya".

Seseorang yang berpikir negatif terhadap tubuhnya menggambarkan bahwa individu tersebut memiliki citra tubuh negatif yaitu tidak merasa puas dengan tubuhnya, sehingga 
membuatnya tidak percaya diri serta prihatin akan keadaan tubuhnya. Citra tubuh negatif merupakan salah satu masalah yang harusnya mampu diatasi para remaja dengan cara merelakan dan menerima segala sesuatu yang ditetapkan oleh Allah ta'ala atas dirinya, dengan kata lain para remaja harus mampu berlaku ridha terhadap apa yang sudah diberikan dan dimilikinya. Menurut Hurlock (Murasmutia, Hardjajani, \& Nugroho, 2015) kepuasan terhadap fisik akan menimbulkan sikap positif yang diekspresikan dalam bentuk rasa percaya diri, keyakinan diri, dan konsep diri yang sehat. Tujuan penelitian untuk membuktikan adanya hubungan ridha terhadap citra tubuh remaja pada siswa SMAN X di Kabupaten Paser Kalimantan Timur.

\section{Metode}

Jenis penelitian ialah korelasional dengan pendekatan kuantitatif. Penelitian ini menggunakan variabel bebas ridha dan variabel terikat citra tubuh. Penelitian dilakukan di SMAN X di Kabupaten Paser Kalimantan Timur dengan jumlah subjek sebanyak 124 siswa kelas XI. Teknik pengambilan sampel menggunakan purposive sampling dengan karakteristik, pertama siswa kelas XI, kedua beragama Islam, ketiga usia 17-18 tahun dan keempat bukan siswa pindahan dalam jangka waktu kurang dari 3 bulan.

\section{Skala Ridha}

Skala ridha terdiri dari 26 aitem berdasarkan dimensi-dimensi ridha dari Abdul Mujib (2017)yaitu perilaku qolbu dan perilaku fisik, dengan koefisien reliabilitas 0,859 dan daya beda aitem bergerak dari angka 0,278-0,634.

\section{Skala Citra Tubuh}

Skala citra tubuh terdiri dari 22 aitem yang diadopsi dan dimodifikasi berdasar pada skala citra tubuh dari Cash. Adapun dimensi-dimensi citra tubuh menurut Cash (Wiranatha \& Supriyadi, 2015) yaitu evaluasi penampilan, orientasi penampilan, kecemasan menjadi gemuk, pengkategorian ukuran tubuh, dan kepuasan terhadap bagian tubuh. Adapun koefisien reliabilitas sebesar 0,834 dengan daya beda aitem bergerak dari 0,264 - 0,635. 


\section{Hasil-hasil}

Teknik analisis menggunakan analisis product moment dibantu dengan software Statistical Packages for Social Science (SPSS) 21.0 for Windows.

Tabel 1

Statistik deskriptif

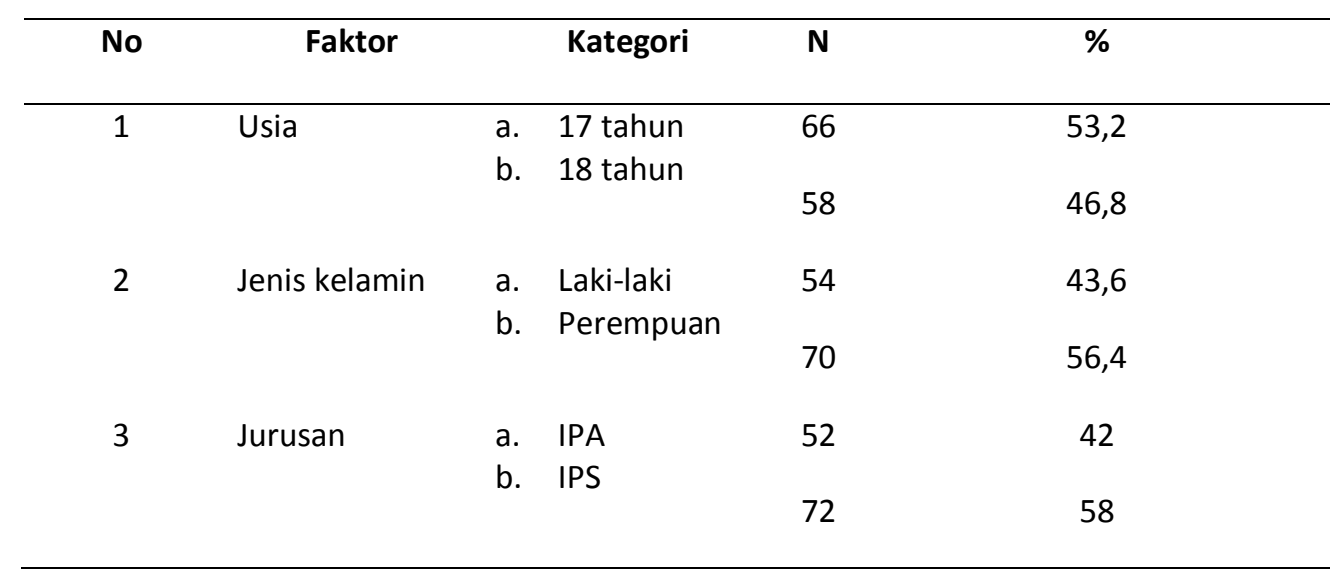

Tabel 2

Uji Normalitas

\begin{tabular}{lcc}
\hline Variabel & Ridha & Citra Tubuh \\
\hline Sig. & 0,711 & 0,203 \\
\hline
\end{tabular}

Adapun uji normalitas yang digunakan peneliti ialah uji Kolmogrov-Smirnov tanpa koreksi Lilliefor. Berdasarkan hasil uji normalitas nilai p untuk variabel ridha dan citra tubuh adalah $\mathrm{p}=0,711 ; 0,203(\mathrm{p}>0,05)$ sehingga data dinyatakan berdistribusi normal. 
Tabel 3

Uji Linieritas

\begin{tabular}{|c|c|c|c|c|c|c|c|}
\hline & & & $\begin{array}{l}\text { Sum of } \\
\text { Squares }\end{array}$ & Df & $\begin{array}{l}\text { Mean } \\
\text { Square }\end{array}$ & $F$ & Sig. \\
\hline \multirow{10}{*}{$\begin{array}{l}\text { Citra } \\
\text { Tubuh* } \\
\text { Ridha }\end{array}$} & & (Combined) & 1764.353 & 36 & 49.010 & 1.358 & .125 \\
\hline & & Linearity & 514.584 & 1 & 514.584 & 14.26 & .000 \\
\hline & Between & & & & & 1 & \\
\hline & Groups & & & & & & \\
\hline & & Deviation & 1249.768 & 35 & 35.708 & .990 & .499 \\
\hline & & from & & & & & \\
\hline & & Linearity & & & & & \\
\hline & Within & & 3139.285 & 87 & 36.084 & & \\
\hline & Groups & & & & & & \\
\hline & Total & & 4903.637 & 123 & & & \\
\hline
\end{tabular}

Tabel 4

Measure of Association

\begin{tabular}{lrrrrr}
\hline & R & R Squared & Eta & \multicolumn{2}{c}{ Eta Squared } \\
\hline CitraTubuh*Ridha & .324 & .105 & .600 & & .360 \\
\hline
\end{tabular}

Uji linieritas yang digunakan ialah test for linearity $\mathrm{p}=0,000(0,000<0,05)$ yang artinya hubungan antara ridha dan citra tubuh linier, sehingga bisa dilanjutkan uji korelasi. Pada tabel measures of association dapat dilihat angka sumbangan efektif atau pengaruh variabel bebas terhadap variabel terikat pada kolom $R^{2}$ atau $R$ Square. Berdasarkan angka $R^{2}$ bahwa ridha memberikan sumbangan efektif atau pengaruh terhadap variabel citra tubuh sebesar 10,5\%.

Tabel 5

Uji Hipotesis

\begin{tabular}{|c|c|c|c|}
\hline & & Ridha & Citra Tubuh \\
\hline \multirow{3}{*}{ Ridha } & Pearson Correlation & 1 & $.324^{* *}$ \\
\hline & Sig. (1-tailed) & & .000 \\
\hline & $\mathrm{N}$ & 124 & 124 \\
\hline \multirow{3}{*}{ Citra Tubuh } & Pearson Correlation & $.324^{* *}$ & 1 \\
\hline & Sig. (1-tailed) & .000 & \\
\hline & $\mathrm{N}$ & 124 & 124 \\
\hline
\end{tabular}


Uji hipotesis menggunakan uji korelasi product moment dari Pearson. Berdasarkan hasil uji korelasi product moment bahwa ada hubungan positif antara ridha dengan citra tubuh yang tunjukkan oleh $\mathrm{p}=0,000$ atau $(\mathrm{p} \leq 0,01)$ dengan $\mathrm{r}_{\mathrm{xy}}=0,324$. Sehingga hipotesis dapat diterima, yaitu ada hubungan positif antara ridha dengan citra tubuh remaja pada siswa SMA yang artinya semakin tinggi keridhaan seseorang maka semakin positif citra tubuh.

\section{Pembahasan}

Hasil analisis data skala ridha dan skala citra tubuh menunjukkan bahwa ada hubungan positif antara ridha dengan citra tubuh remaja pada siswa SMA, berdasarkan hasil uji korelasi product moment yaitu $\mathrm{r}_{x y}=0,324 ; \mathrm{p}=0,000(\mathrm{p}<0,01)$ sehingga ridha dinyatakan memiliki hubungan positif terhadap citra tubuh dan $\mathrm{Ha}$ atau hipotesis kerja dapat diterima. Seseorang dengan tingkat ridha yang baik ialah mereka yang rela dan menerima terhadap apa yang diberikan oleh Allah Ta'ala. Hal ini didukung oleh pendapat Mujib (2017), yaitu seseorang yang ridha ialah mereka yang rela dan menerima terhadap apa yang diberi dan dimiliki. Chaplin (Ridha, 2013) menjelaskan bahwa penerimaan diri merupakan sikap yang pada dasanya merasa puas dengan diri sendiri, kualitas-kualitas dan bakat-bakat diri serta pengakuan akan keterbatasan diri.

Penerimaan diri merupakan bagian dari menerima takdir dengan kerelaan hati termasuk menerima kekurangan maupun kelebihan yang terdapat pada tubuh sendiri, kemudian hal tersebut dikenal pula dengan citra tubuh. Seseorang yang rela dan menerima dengan segala kondisi tubuhnya ialah individu yang memiliki citra tubuh positif. Menurut Thompson (Husni \& Indrijati, 2014) individu yang memiliki citra tubuh positif mencerminkan tingginya penerimaan jati diri, rasa percaya diri, dan kepedulian yang tinggi terhadap kondisi badan dan kesehatannya. Hubungan positif antara ridha terhadap citra tubuh remaja pada siswa SMA juga didukung oleh penelitian sebelumnya. Seperti penelitian yang dilakukan oleh Rahmawati dkk (2016), tentang hubungan antara kebersyukuran dengan citra tubuh pada mahasiswi menyatakan bahwa ada hubungan positif antara kebersyukuran dengan citra tubuh. 
Adapun nilai $\mathrm{R}^{2}$ yang didapat sebesar $10,5 \%$ artinya ridha memberikan sumbangan efektif terhadap citra tubuh remaja sebesar 10,5\%. Maka ini menunjukkan bahwa ridha memiliki peran dalam mempengaruhi citra tubuh.

Subjek penelitian yaitu remaja yang bersekolah di SMAN X dengan kisaran usia antara 17-18 tahun. Menurut Dinc dan Alisinanoglu (Nugraha, 2014) bahwa pada usia remaja seseorang sangat memperhatikan citra tubuh. Hasil wawancara peneliti terhadap salah satu guru bimbingan konseling (BK) menyebutkan jika di sekolah masalah penampilan lebih banyak dilakukan oleh siswa daripada siswi. Hasil kategori tingkatan ridha dan citra tubuh dalam penelitian menunjukkan bahwa kategori rendah lebih mendominasi. Secara tidak langsung kategori ini menjelaskan bahwa jumlah siswa dengan citra tubuh negatif cukup banyak daripada siswa yang berada pada kategori sedang dan tinggi. Penilaian yang salah atau negatif terhadap berat badan serta ketidakpuasan terhadap bagian-bagian tubuh disebut sebagai citra tubuh negatif (Tauran, 2014). Cash dan Grant (Tauran, 2014) menyebutkan bahwa seseorang dengan citra tubuh negatif cenderung memiliki harga diri yang rendah, dapat menyebabkan kecemasan dan menarik diri dari lingkungan sosial oleh karenanya hadirlah perilaku amat memperhatikan penampilan seperti yang disebutkan Santrock dan selain itu perilaku mengubah bentuk tubuh seperti pada penelitian Dwinanda, meskipun angka pelakunya tidak terlalu besar. Mengubah bentuk tubuh yang dimaksud berupa sulam alis, suntik pemutih dan mencukur rambut tidak sesuai peraturan sekolah. Kemudian adapula yang mengubah penampilan dari pakaian seperti mengecilkan celana menjadi celana pensil, adapula yang memperkecil ukuran baju dan rok sekolah serta menggunakan riasan pada jam sekolah maupun kegiatan di luar jam sekolah seperti lipstik dan eyeshadow.

\section{Kesimpulan}

Berdasarkan hasi penelitian dapat disimpulkan bahwa terdapat hubungan positif antara ridha dengan citra tubuh remaja pada siswa SMAN X di Kabupaten Paser Kalimantan Timur dengan nilai koefisien korelasi $\mathrm{r}_{x y}=0,324 ; \mathrm{p}=0,000(\mathrm{p}<0,01)$. Berdasarkan nilai $R$ Square ridha memberi sumbangan efektif sebesar 0,105 atau 10,5\% terhadap citra tubuh remaja. Pada pengkategorian masing-masing variabel didapat nilai mean dengan kategori rendah 
mendominasi para siswa yaitu 39,50\% dan 37,90\%. Dari jumlah subjek sebanyak 124 sampel kurang lebih 50 orang berada pada kategori rendah. Sehingga hal tersebut menjelaskan bahwa tingkat ridha yang rendah menyebabkan citra tubuh menjadi negatif begitu pula sebaliknya tingkat ridha yang tinggi menyebabkan citra tubuh menjadi positif.

\section{Saran}

Disarankan untuk melakukan penelitian lanjutan berupa eksperimen seperti intervensi kebersyukuran, terapi membaca alquran maupun perlakuan lainnya yang mampu meningkatkan sikap ridha sehingga efeknya menyebabkan citra tubuh menjadi positif. Kemudian menyempurnakan penelitian dari segi teori, proses pembuatan alat ukur, dan riset lapangan. Lalu memperkaya penelitian dengan mengkorelasikan variabel lain yang sebelumnya belum pernah dikorelasi. Membaca dan mempelajari buku-buku psikometri terutama mengenai prosedur pengujian alat ukur, cara menguji data, cara membaca dan mendeskripsikan hasil uji data seperti reliabilitas, validitas, uji prasyarat dan uji hipotesis.

\section{Referensi}

al-Jauziyah, I. Q. (1998). Madarijus Salikin (Pendakian Menuju Allah): Penjabaran Kongkret "Iyyaka Na'budu wa Iyyaka Nasta'in". terj. Kathur Suhardi. Jakarta: Pustaka al-Kautsar.

al-Maqdisy, I. Q. (2012). Minhajul Qashidin: Menggapai kebahagian hidup dunia dan akhirat. terj. Irfanuddin Rafi'uddin. Jakarta: Pustaka as-Sunah.

al-Mundziri, I. (2003). Ringkasan hadis shahih muslim. terj. Achmad Zaidun. Jakarta: Pustaka Amina.

Dwinanda, R. F. (2017). Hubungan gratitude dengan citra tubuh pada remaja. Jurnal Ilmiah Psikologi, 9(1).

Hasni, N. I., Karini, S. M., \& Andayani, T. R. (2013). Hubungan antara Citra Tubuh Saat Hamil dan Kestabilan Emosi dengan Postpartum Blues di Puskesmas Grogol Sukoharjo. Jurnal Ilmiah Psikologi Candrajiwa, 2(1).

Hurlock, E. B. (1980). Psikologi Perkembangan: Suatu Pendekatan Sepanjang Rentang Kehidupan (5 ed.). Jakarta: Erlangga.

Husni, H. K., \& Indrijati, H. (2014). Pengaruh Komparasi Sosial pada Model pada Iklan Kecantikan di Televisi Terhadap Body Image Remaja Putri yang Obesitas. Jurnal Psikologi Pendidikan dan Perkembangan, 3(3), 207-209.

Kemdikbud. (2017). Kamus Besar Bahasa Indonesia Online, ed. Ebta Setiawan. Diakses 3 Desember 2017, dari https://kbbi.web.id/ridha.

Mujib, A. (2017). Teori Kepribadian Perspektif Psikologi Islam (2 ed.). Jakarta: Rajawali Press.

Munawwir, A. W. (1997). Al Munawwir: Kamus Arab - Indonesia. Surabaya: Pustaka Progresif. 
Murasmutia, A., Hardjajani, T., \& Nugroho, A. A. (2015). Hubungan Antara Citra Tubuh dan Kepercayaan Diri dengan Perilaku Konsumtif terhadap Pakaian pada Mahasiswi Fakultas Hukum Universitas Sebelas Maret Surakarta. Jurnal Ilmiah Psikologi Candrajiwa, 4(3 Des).

Nugraha, F. A. (2014). Hubungan antara body image, self-esteem dan prestasi akademik pada mahasiswa Fakultas Indonesia Universitas Indonesia (Skripsi). Universitas Indonesia, Depok.

Ridha, M. (2013). Hubungan antara body image dengan penerimaan diri pada mahasiswa Aceh di Yogyakarta. Empathy Jurnal Fakultas Psikologi, 1(1).

Sarwer, D. B., Thompson, J. K., \& Cash, T. F. (2005). Body image and obesity in adulthood. Psychiatric Clinics, 28(1), 69-87.

Tauran, P. (2014). Hubungan antara body image dengan kapasitas intimacy terhadap lawan jenis pada mahasiswa fakultas Psikologi universitas Padjadjaran (Skripsi). Universitas Padjadjaran, Bandung.

Wiranatha, F. D., \& Supriyadi. (2015). Hubungan Antara Citra Tubuh Dengan Kepercayaan Diri Pada Remaja Pelajar Puteri Di Kota Denpasar. Jurnal Psikologi Udaya, 2.

Yuliadi, I., \& Karyanta, N. A. (2014). Hubungan antara Body Image dan Imaginary Audience dengan Kepercayaan Diri pada Siswi Kelas X SMA Negeri 2 Nganjuk. Jurnal Ilmiah Psikologi Candrajiwa, 3(3). 